\title{
Long Term Impact in Reinforced Recycled Concrete Beams Under 9-Month Loading
}

\author{
Mahboob Oad \\ Department of Civil Engineering, Quaid-e-Awam University of \\ Engineering, Science \& Technology, Nawabshah, Pakistan \\ engrmahboob04@gmail.com
}

\section{Bashir Ahmed Memon}

Department of Civil Engineering, Quaid-e-Awam University of Engineering, Science \& Technology, Nawabshah, Pakistan basher_m@hotmail.com

\author{
Abdul Hafeez Buller \\ Department of Civil Engineering, Quaid-e-Awam University of \\ Engineering, Science \& Technology, Nawabshah, Pakistan \\ ah.buller@quest.edu.pk
}

Noor Ahmed Memon

Department of Civil Engineering, Quaid-e-Awam University of Engineering, Science \& Technology, Nawabshah, Pakistan nahmedmemon@gmail.com

\author{
Samiullah Sohu \\ Department of Civil Engineering, Quaid-e-Awam University College \\ of Engineering, Science \& Technology, Pakistan \\ sohoosamiullah@gmail.com
}

\begin{abstract}
Green concrete is an active area of research. Structural demolishing waste is a global serious problem, particularly in urban areas. This research paper presents the experimental evaluation of the effect of long term loading on reinforced green concrete beams. Three beams were cast with partial replacement of natural coarse aggregates with demolished old concrete. Three beams were cast with all-natural coarse aggregates to compare the results. The beams were mounted on purpose made frames for 9 months. Deflection, strain and cracking in beams were monitored on a daily basis. After 9 months, the beams were tested until failure in a universal load testing machine under central point load. It was observed that the proposed beams exhibited $3.55 \%$ reduction in maximum load caring capacity compared to control specimens. The obtained results show good performance of the proposed green concrete beams under 9-month long term loading.
\end{abstract}

Keywords-green concrete; demolished concrete; coarse aggregates; long-term loading flexural strength; deflection

\section{INTRODUCTION}

The production of conventional concrete ingredients gave rise to several environmental issues. The rapid pace of development around the globe consumes these ingredients in large quantities. Green concrete is the best solution to not only protect environment to some extent, but also to save natural resources for the future. The use of old, demolished concrete in new concrete, in full or partial replacement of coarse aggregates is an active area of research the last two decades. In this regard, author in [1] reviewed the recent trends regarding the use of demolished concrete as partial or full replacement of coarse aggregates in new concrete. Under short term loading, authors in $[2,3]$ studied the flexural stress-strain behavior of reinforced recycled concrete beams using normal and rich mix concrete. From the obtained results they observed $8.8 \%$ and $11.68 \%$ reduction in flexural capacity of 28 -day cured normal and rich mix beams respectively. In addition to short term loading, structures also have to face random jerks (wind and earthquake) and long-term/sustained loading during their service life. Therefore, it is essential to check the performance of the proposed concrete under long-term loading to study the behavior of the material and improve the confidence in using it. To this end, shrinkage, creep and deflection under long-term loading using recycled aggregates and high volumes of fly ash were studied in [4]. Authors reported that all studied parameters showed increase with increase in dosage of recycled aggregates. Authors in [5] extended the study to concrete creep and shrinkage. They used four replacement levels of coarse aggregates, namely $0 \%, 20 \%, 50 \%$ and $100 \%$ and two different water-cement ratios, 0.5 and 0.65 for 1000 days in order to study the parameters. Their observations were almost the same with the ones presented in [3]. They also recorded different behavior of the parameters when they used pre-saturated coarse aggregates. They also developed a numerical expression to predict the parameters of the study. Authors in [6] also studied long-term deflection. Authors in [10] studied the flexural capacity of recycled concrete beams under the combined effect of corroded steel and sustained loading. They observed reasonable performance of the proposed material under longterm loading.

Pore size and mechanical properties of concrete with recyclable aggregates from different sources were experimentally investigated in [8]. The authors used 5-year 
cured samples of the proposed concrete. From the obtained results, they observed good correlation between porosity and strength of the concrete. Comparison of experimental creep and shrinkage of recyclable concrete specimens under 1-year sustained loading with ACI provisions was made in [7]. Using their observations, the authors suggested modifications in the equation given by ACI provisions. The modified equation was then used to check the experimental data of the parameters with good agreement. Old concrete aggregates have old mortar attached with them. This not only increases the water demand of the concrete, but also has effect on its performance. The effect of mortar attached with old concrete aggregates has been studied in [9]. Based on their study results, authors introduced residual-mortar-factor to existing ACI and CEB methods used for computation of creep and drying shrinkage. Comparison of the results using residual-mortar-factor and original formulation revealed better results with the proposed factor.

Authors in [11] used cylinders as coarse aggregates in production of reinforced recycled concrete beams to test for flexure, shear and bond. They used $40 \%$ and $100 \%$ replacement of natural coarse aggregates and control specimen with $0 \%$ recyclable aggregates. The comparison of test results with control specimen, ACI provisions and similar results from the literature revealed minimal differences in peak load and loaddeflection. They also used finite element method to model the obtained results. The results of the numerical model were in good agreement with the experimental observations. Authors in [12] designed a 1200-day long-term deformation test on reinforced concrete beams made with $0 \%, 50 \%$ and $100 \%$ replacement of natural coarse aggregates with recycled aggregates. They introduced creep coefficient of recycled aggregates in the computation of additional curvature of the beam section to develop formulas for the calculation of longterm deflection. They also introduced the regeneration coefficient based on the size of recycled aggregates. Finally, they developed the deflection increase coefficient which simplifies the computation of long-term deflection and the results obtained by the use of the coefficient agree well with the experimental results.

The above discussion of the available relevant literature shows that there still is room for more research to build confidence in the use of recyclable demolished concrete as coarse aggregates in new, green concrete. Therefore, in this work, the long-term effect of 9-month loading on reinforced concrete beams was evaluated. The beams were cast with $50 \%$ dosage [13] of recyclable aggregates from demolished concrete.

\section{MATERIALS AND TESTING}

\section{A. Materials}

For casting of the proposed beams, ordinary Portland cement under the brand name Pak Land, hill sand, natural coarse aggregates of size approximately equal to $25 \mathrm{~mm}$ and demolished concrete as coarse aggregates were used. Large blocks of demolished concrete were collected from demolishing waste of an about 45 years old building. These blocks were manually hammered to get aggregate size approximately equal to $25 \mathrm{~mm}$ as of the natural coarse aggregates. After washing and drying the aggregates in open air, screening of the aggregates for cracked particles was done to avoid the use of weak material. Sieve analysis of both natural and recyclable aggregates was done in accordance with relevant (ASTM C 136) procedure to have well graded aggregates in the concrete mix (Table I).

TABLE I. COARSE AGGREGATES SIEVE ANALYSIS

\begin{tabular}{|c|c|c|c|c|}
\hline \multirow{2}{*}{ S.No } & \multicolumn{2}{|c|}{ Sieve } & \multicolumn{2}{|c|}{$\%$ Passing } \\
\hline & Mm & in/\# & RCA & NCA \\
\hline 1 & 31.5 & 1.25 & 100.00 & 100.00 \\
\hline 2 & 25.0 & 1.00 & 93.60 & 94.11 \\
\hline 3 & 19.0 & 0.75 & 47.21 & 48.26 \\
\hline 4 & 12.5 & 0.50 & 18.25 & 17.82 \\
\hline 5 & 9.5 & 0.38 & 5.74 & 5.41 \\
\hline 6 & 4.8 & $\# 4$ & 2.43 & 2.29 \\
\hline 7 & 2.36 & $\# 8$ & 1.13 & 2.23 \\
\hline 8 & \multicolumn{2}{|c|}{ Pan } & - & - \\
\hline
\end{tabular}

Both natural and recyclable aggregates were used in 50\% proportion. 1:2:4 concrete mix with 0.5 water-cement ratio was used because it is commonly used in the construction industry. Potable water from the city water supply system with $\mathrm{pH}$ value equal to 6.9 was used in the concrete mix. Deformed bars of 60 grade strength were used as reinforcement.

\section{B. Model}

A total of 9 reinforced concrete beams were cast. The dimensions of all the beams were kept equal to $1875 \mathrm{~mm} \times 150 \mathrm{~mm} \times 300 \mathrm{~mm}$. Weight batching ingredients of concrete were adopted. To reinforce the beams four \#4 bars were used as longitudinal reinforcement ( 2 bars in tension and 2 bars in compression zones). Shear reinforcement in the form of stirrups was provided at $150 \mathrm{~mm}$ center to center along the length of the beams. Six beams were cast with all-natural coarse aggregates. Out of these, three beams were used for the determination of peak load under short term loading, whereas the remaining three beams were used for long-term load testing. Three beams were cast with $50 \%$ dosage of natural and recycled aggregates. In all beams, top and bottom concrete cover were kept equal to $25 \mathrm{~mm}$. Concrete mixer was used for mixing the ingredients, followed by casting of the beams in standard fashion. All the beams were cured for 28 days by fully immersing in potable water. After curing, beams were allowed to air dry for 24 hours, followed by installation of dumec pads in 11 rows at equidistant from center line of the beams for strain measurement.

\section{Testing}

Before starting the long-term loading test of the beams, three beams made with all-natural aggregates were tested in universal load testing machine using central point load (ASTM C 193) for short term loading. The average peak load of the three beams was recorded to be $74.022 \mathrm{KN}$, and $50 \%$ of this load was used as sustained load for long-term loading tests. Out of the remaining six beams, three of all-natural aggregates (NB1, NB2, NB3) and three beams with $50 \%$ dosage of recyclable aggregates (RB1, RB2, RB3) from demolished 
concrete were mounted on long-term load testing frame (Figure 1). The load was applied on the center of the beams with the help of a load cell and screw jack system and was maintained for 9 months. During this period of time, load, deflection, strain and cracking were measured on daily basis.

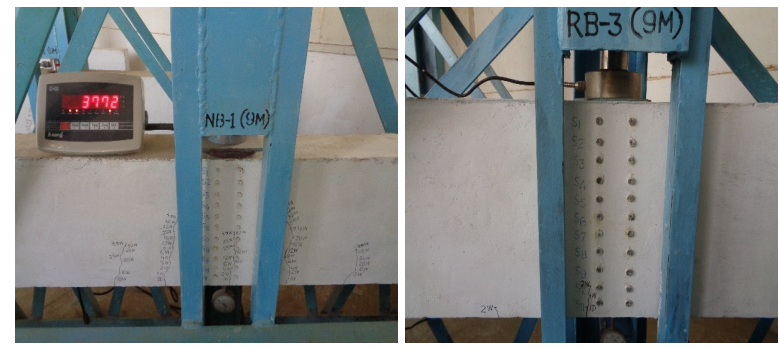

Fig. 1. Beams mounted on loading frame.

After the elapse of the 9-month period, the load was removed. The beams were then tested in the universal load testing machine. During the testing, load, deflection and cracking were recorded at regular intervals.

\section{RESULTS AND DISCUSSION}

The parameters were recorded on a daily basis. The strain was recorded on eleven locations along the depth of the beams. The average of all strain values was computed. The deflection, its average and difference between both groups of the beams is given in Table II. The strain results are given in Table III. It may be observed that the proposed beams in comparison to control specimen under sustained load for 9 months exhibited $6.235 \%$ increase in deflection and $6.322 \%$ increase in strain. It was further observed that the maximum deflection in the proposed beams is within the allowable limits specified by ACI 318. Figure 2 shows the average deflection vs. time and Figure 3 shows the average strain vs. time. It is clear from these figures that both deflection and strain were increased due to the introduction of recycled aggregates in concrete. The trend of deflection and strain gain is the same in both types of the beams. All the beams were also tested under central point load in accordance to ASTM C 293 specifications until failure. During the process, load and deflections were monitored at regular intervals. The maximum load sustained by the beams made with all-natural aggregate was recorded equal to $83.150 \mathrm{KN}$ with deflection equal to $13.2 \mathrm{~mm}$ while in beams with recyclable aggregates was equal to $80.200 \mathrm{KN}$ and $13.78 \mathrm{~mm}$ respectively. The load vs. deflection of all six beams is shown in Figure 4. Except some minor jerks, the deflection patterns of all the beams are similar, recycled aggregate beams are in good agreement with all-natural aggregate beams. The reduction in maximum attained load of beams with recyclable aggregates is recorded equal to $3.55 \%$ whereas the increase in deflection is equal to $4.39 \%$, both less than $5 \%$. During the sustained loading cracks were monitored and marked (Figure 5). The widest crack at the end of testing was recorded to be less than $1 \mathrm{~mm}$. This shows the strength of the proposed beams under sustained loading. After sustained loading and during the testing of the beams, the crack pattern in almost all the beams is shear failure (Figure 6). From the obtained results it is very clear that the reinforced concrete beams made with $50 \%$ replacement of natural coarse aggregates with recyclable aggregates perform well under 9-month sustained loading.

TABLE II. AVERAGE DEFLECTION IN ALL BEAMS

\begin{tabular}{|c|c|c|c|}
\hline B\# & Deflection (mm) & Average & Difference \% \\
\hline NB-1 & 2.2050 & \multirow{3}{*}{2.165} & \multirow{2}{*}{6} \\
\cline { 1 - 2 } NB-2 & 2.1225 & \multirow{2}{*}{6.235} \\
\hline NB-3 & 2.1700 & & \\
RB-1 & 2.2950 & \multirow{2}{*}{2.300} & \\
\hline RB-2 & 2.3375 & \\
\hline RB-3 & 2.2650 & & \\
\hline
\end{tabular}

TABLE III. AVERAGE STRAIN IN ALL BEAMS

\begin{tabular}{|c|c|c|c|}
\hline B\# & Strain & Average & Difference \% \\
\hline NB-1 & 0.00244 & \multirow{3}{*}{0.002420} & \\
NB-2 & 0.00239 & \multirow{2}{*}{0.322} \\
\cline { 1 - 2 } NB-3 & 0.00242 & & \\
\cline { 1 - 2 } RB-1 & 0.00257 & \multirow{3}{*}{0.002573} & \\
\cline { 1 - 2 } RB-2 & 0.00261 & \\
\cline { 1 - 2 } RB-3 & 0.00254 & & \\
\hline
\end{tabular}

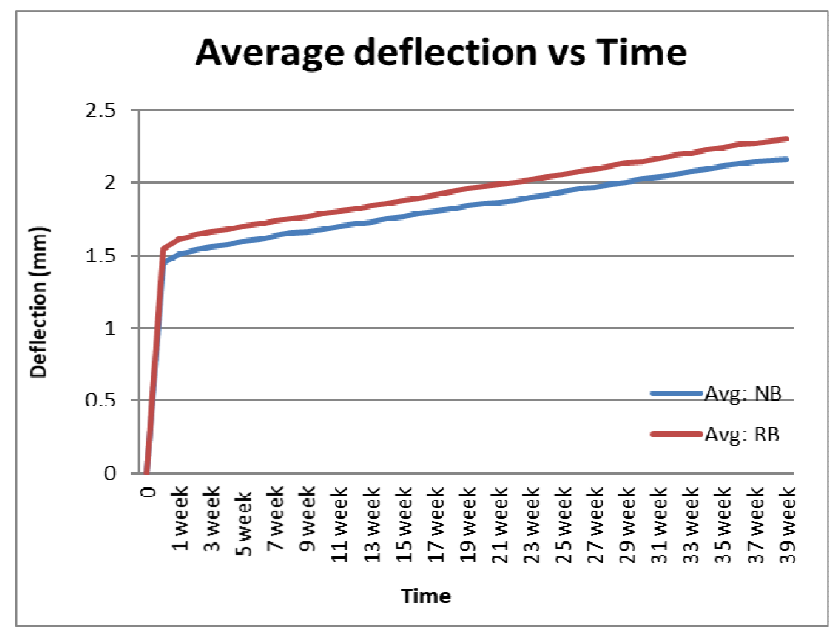

Fig. 2. Average deflection vs time

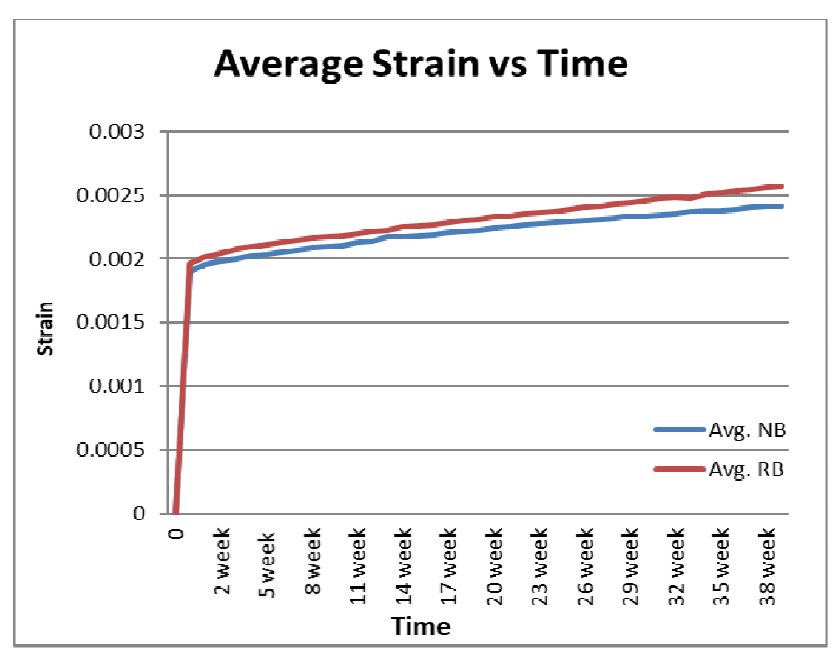

Fig. 3. Average strain vs time 


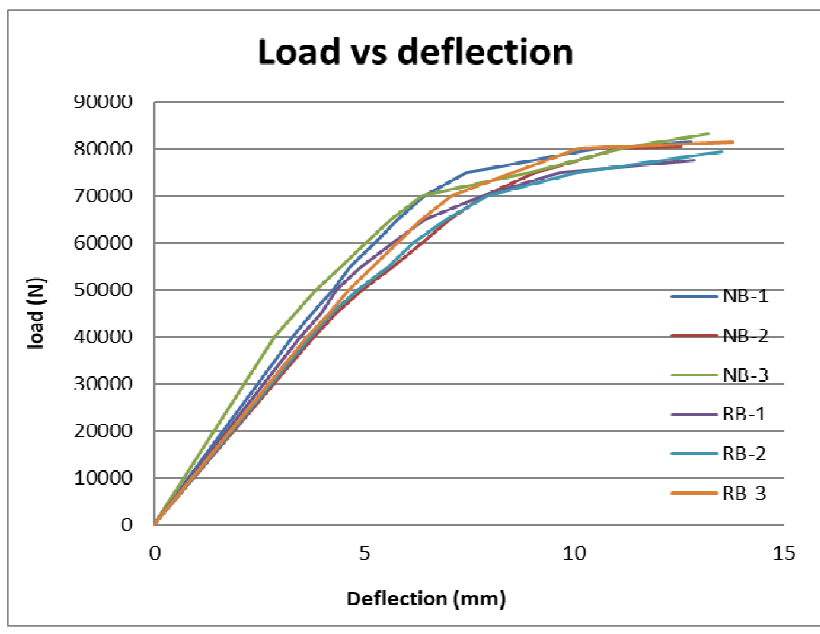

Fig. 4. Load vs deflection

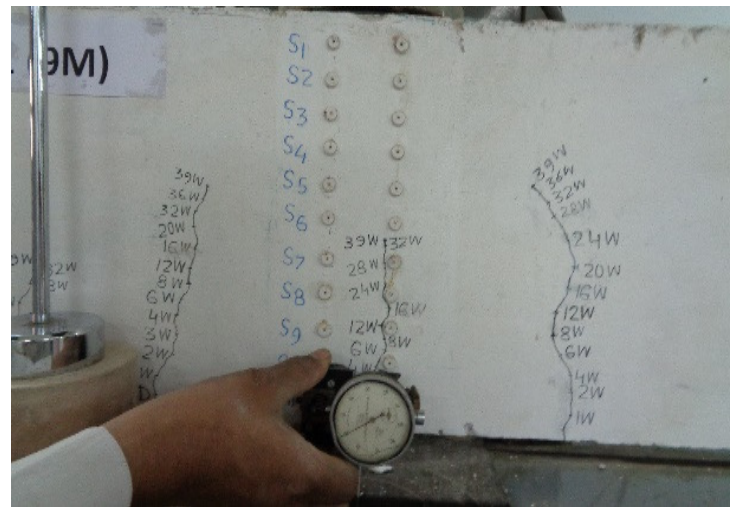

Fig. 5. Cracking under sustained load

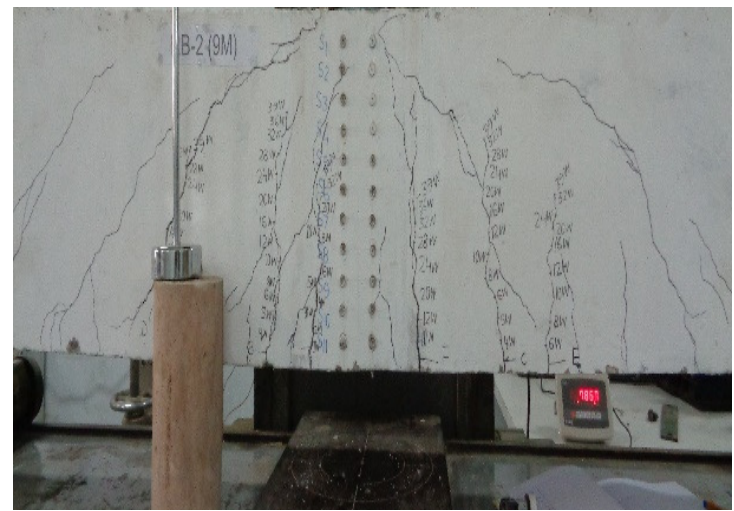

Fig. 6. Failure pattern

\section{CONCLUSION}

This research aimed to evaluate the effect of 9-month sustained load on reinforced concrete beams made with $50 \%$ dosage of recycled aggregates from demolished concrete. The test results of the proposed beams tested in a purpose made frame for 9 months under central point load show that the maximum deflection attained by the beams is $2.3 \mathrm{~mm}$ which is only $6.235 \%$ higher than the maximum deflection of control beams. Similar increase in strain is recorded, equal to $6.322 \%$. Crack initiation and propagation was also recorded and was observed that at the end of the 9-month period, the maximum width was $0.52 \mathrm{~mm}$. After the removal of sustained load, the beams were tested in UTM until failure. During testing, load and deflection pattern of the beams remained in good agreement to each other. It was also observed that almost all the beams failed in shear test. The observations demonstrate that reinforced concrete beams made with $50 \%$ recycled aggregates showed good performance under 9-month sustained loads.

\section{REFERENCES}

[1] B. A. Memon., "Recent Development on Use of Demolished Concrete as Coarse Aggregates", International Journal of Emerging Technology and Innovative Engineering, Vol. 2. No. 1, pp. 1-11, 2016

[2] M. Oad, A. H. Buller, B. A. Memon, N. A. Memon. S. Sohu, "Flexural Stress-Strain Behavior of RC Beams made with Partial Replacement of Recyclable Concrete Aggregates, Part-2: Rich Mix", Engineering Technology and Applied Science Research, Vol. 8, No. 5, pp. 33383343, 2018

[3] M. Oad, A. H. Buller, B. A. Memon, N. A. Memon, "Flexural StressStrain Behavior of RC Beams made with Partial Replacement of Coarse Aggregates with Coarse Aggregates from Old Concrete: Part-1 (1:2:4 Ratio)", Engineering Technology and Applied Science Research, Vol. 8, No. 3, pp. 3048-3053, 2018

[4] N. Tosic, S. Marinkovic, N. Pecic, I. Ignjatovic, J. Dragas, "Long-Term Behavior of Reinforced Beams made with Natural or Recycled Aggregate Concrete and High-Volume Fly Ash Concrete", Construction and Building Materials, Vol. 176, pp. 344-358, 2018

[5] S. Seara-Paz, B. Gonzalez-Fonteboa, F. Martinez-Abella, I. GonzalezTaboada, "Time-Dependent Behavior of Structural Concrete made with Recycled Coarse Aggregates. Creep and shrinkage", Construction and Building Materials, Vol. 122, pp. 95-109, 2016

[6] S. Seara-Paz, B. Gonzalez-Fonteboa, F. Martinez-Abella, D. CarroLopez, "Long-Term Performance of Reinforced Concrete Beams with Recycled Coarse Aggregates", Construction and Building Materials, Vol. 176, pp. 593-607, 2018

[7] W. C. Choi, H. D. Yun, "Long-Term Deflection and Flexural Behavior of Reinforced Concrete Beams with Recycled Aggregates", Materials and Design, Vol. 51, pp. 742-750, 2013

[8] S. C. Kou, C. S. Poon, M. Etxeberria, "Influence of Recycled Aggregates on Long-Term Mechanical Properties and Pore Size Distribution of Concrete", Cement and Concrete Composites, Vol. 33, No. 2, pp. 286-291, 2011

[9] G. Fathifazl, A. G. Razaqpur, O. B. Isgor, A. Abbas, B. Fournier, S. Foo, "Creep and Drying Shrinkage Characteristics of Concrete Producedwith Coarse Recycled Concrete Aggregate", Cement \& Concrete Composites, Vol. 33, No. 10, pp. 1026-1037, 2011

[10] A. Lapako, R. Grygo, "Long-Term Deformations of Recycled Aggregate Concrete (RAC) Beams made of Recycled Aggregates", 10th International Conference on Modern Building Materials, Structures and Techniques, Vilnius Lithuania, May 19-21, 2010

[11] B. S. Hamad, A. H. Dawi, A. Daou, G. R. Chehab, "Studies of the Effect of Recycled Aggregates on Flexural, Shear and Bond Splitting Beam Structural Behavior", Case Studies in Construction Materials, Vol. 9, pp. e00186, 2018

[12] C. Liu, Z. Y. Lv Z, C. Zhu, G. L. Bai, Y. Zhang, "Study on Calculation Method of Long-Term Deformation of RAC Beam based on Creep Adjustment Coefficient”, KSCE Journal of Civil Engineering, Vol. 23, No. 1, pp. 260-267, 2019

[13] M. Oad, B. A. Memon, "Compressive Strength of Concrete Cylinders using Coarse Aggregates from Old Concrete", 1st National Conference on Civil Engineering, Pakistan, April 28-29, 2014 